\title{
Reproductive ecology of Otocinclus vittatus (Regan, 1904) in the Pantanal floodplain, upper Paraguay River basin
}

\author{
M. J. Pereira ${ }^{a}$ and Y. R. Súarez ${ }^{b}$ \\ aPrograma de Pós-graduação em Recursos Naturais, Universidade Estadual de Mato Grosso do Sul - UEMS, \\ Rodovia Dourados - Itahum, Km 12, CEP 79804-970, Dourados, MS, Brasil

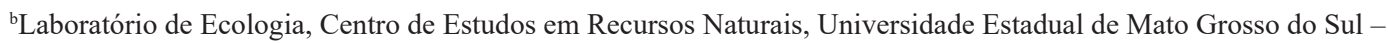 \\ UEMS, Rodovia Dourados - Itahum, Km 12, CEP 79804-970, Dourados, MS, Brasil \\ *e-mail:maianejardim@gmail.com
}

Received: February 15, 2018 - Accepted: April 9, 2018 - Distributed: November 30, 2019

(With 6 figures)

\begin{abstract}
We studied the reproductive biology of Otocinclus vittatus in the southern Pantanal, Brazil. A total of 1066 fishes were analyzed (490 males, 488 females and 88 individuals of undetermined sex), sampled with a rectangular sieve and a seine net from February/2009 to January/2011. Variations in the sex ratio, seasonality in reproduction, fecundity, and size at first maturity were estimated. No variations were detected in the total sex ratio for the study period as a whole; although ratio has varied over time. The gonadosomatic index varied according to the river level, but not according to water temperature and rainfall. The mean fecundity was estimated at 84.1 oocytes, with a positive correlation with standard length. The size at first maturity (L50) estimated was $18.7 \mathrm{~mm}$ for females and $20.1 \mathrm{~mm}$ for males.
\end{abstract}

Keywords: fecundity, life history, sex ratio, size at first maturity.

\section{Ecologia reprodutiva de Otocinclus vittatus (Regan, 1904) na planície de inundação do Pantanal, bacia do alto rio Paraguai}

\begin{abstract}
Resumo
Estudamos a biologia reprodutiva de Otocinclus vittatus no Pantanal Sul, Brasil. Um total de 1066 peixes foram analisados (490 machos, 488 fêmeas e 88 de sexo indeterminado), amostrados com tela de isca e rede de arrasto entre Fevereiro/2009 e Janeiro/2011. Foram estimadas as variações na proporção sexual, a sazonalidade na reprodução e o tamanho da primeira maturação. Não foi detectada variação na proporção sexual total para o período de estudo como um todo; embora a proporção tenha variado ao longo do tempo. O índice ganadossomático variou de acordo com o nível do rio, mas não de acordo com a temperatura da água e a pluviosidade. A média de fecundidade foi estimada em 84.1 ovócitos, com uma correlação positiva com o comprimento padrão. O tamanho de primeira maturação (L50) foi estimado em $18.7 \mathrm{~mm}$ para fêmeas e $20.1 \mathrm{~mm}$ para machos.
\end{abstract}

Palavras-chave: fecundidade, história de vida, proporção sexual, tamanho de primeira maturação.

\section{Introduction}

Siluriformes comprise approximately $33.6 \%( \pm 1400$ species $)$ of Neotropical fishes (Léveque et al., 2008), of which the Loricariidae are the most species-rich family with 971 valid species (Eschmeyer and Fong, 2018). Belonging to this family and subfamily Hypoptopomatinae the genus Otocinclus Cope, 1871 is composed of 20 species of small (less than $60 \mathrm{~mm} \mathrm{SL}$ ) freshwater catfishes distributed in the Neotropics from Colombia to northern Argentina (Eschmeyer and Fong, 2018). The species Otocinclus vittatus Regan, 1904 is a small armored catfish that is found widely in the Pantanal, where it occurs associated with aquatic macrophytes (e.g., Eichhornia azurea, Polygonum spp. and Urochloa subquadripara) near river banks.
Locally this species is used as ornamental fish, however there is no information about its exploitation/commerce, nor the aspects of its ecology are know. The knowledge of basic biological information (e.g. reproductive period, size at first maturation and fecundity) are important for the management and sustainability of ornamental species, thus, aspects of population dynamics and reproductive traits are extremely important for management of ornamental fishery (Rhyne et al., 2009; Baeza et al., 2013). Some reproductive characteristics are strongly associated with the rainy period, higher temperatures and the increase of river levels (Agostinho et al., 2004) to maximize juvenile 
survival and to speed up their development (Wootton, 1991; Lowe-McConnell, 1999).

The Brazilian Pantanal is the larger wetland area worldwide, with great differences in flood pulse according to geographical position. The southern Pantanal presents an asynchrony between river level, temperature and rainy periods, so the flood pulse occurs both in dry and wet seasons. The reproductive dynamics in fish are directly associated with environmental conditions that are favorable for the development of progeny, such as time periods and locations with greater food supply and habitat availability (Tondato et al., 2014; Barzotto \& Mateus, 2017; Súarez et al., 2017; Santana et al., 2018), therefore, these asynchronous climatologic/hydrologic regimes can affect seasonality in fish reproduction leading to alterations in spawning period and other reproductive traits. The higher levels of the river lead to a greater supply of food, making conditions more favorable to reproduction (Tondato et al., 2013), thus generating the hypothesis that reproductive periods are associated with the increase of river level.

Thus, the present study aimed to investigate the seasonal dynamics of reproduction, by defining the reproductive period, size at first maturity and fecundity, relating seasonal gonadosomatic index to environmental descriptors for Otocinclus vittatus in Porto Murtinho, Pantanal.

\section{Material and Methods}

Fish were sampled monthly from February/2009 to January/2011 in macrophyte patches in the Paraguay and Amonguijá rivers, in a sub-region of the Pantanal, known as Pantanal of Porto Murtinho (Figure 1). A total of 109 sample units were obtained and in 78 samples $O$. vittatus was sampled and in present study are included individuals from 64 sampling sites. Samples were taken during daylight, by means of a rectangular sieve $1.2 \times 0.8 \mathrm{~m}(2 \mathrm{~mm}$ mesh size $)$ and a seine $1.5 \times 5 \mathrm{~m}(2 \mathrm{~mm}$ mesh size $)$. The sieve was maneuvered beneath the vegetation and raised to the surface to remove the captured species at each sampling point. The seine was pulled manually, forming an siege in areas free of obstructions. The samples units were obtained, with non-standardized sampling effort. Specimens were fixed in $10 \%$ formalin and preserved in $70 \%$ ethanol for subsequent identification and biometry, in the laboratory, fishes were identified. Voucher specimens are deposited in the fish collection of UFRGS (\#11164).

For each specimen the standard length $(\mathrm{mm})$, total weight $(\mathrm{g})$, sex, maturation stage and gonad weight $(\mathrm{g})$ were obtained. Using a binocular stereomicroscope the individuals were classified into immature (juveniles), maturing (adults), ripe (ready to spawn) and spawned (oocytes released) according to Vazzoler (1996), and

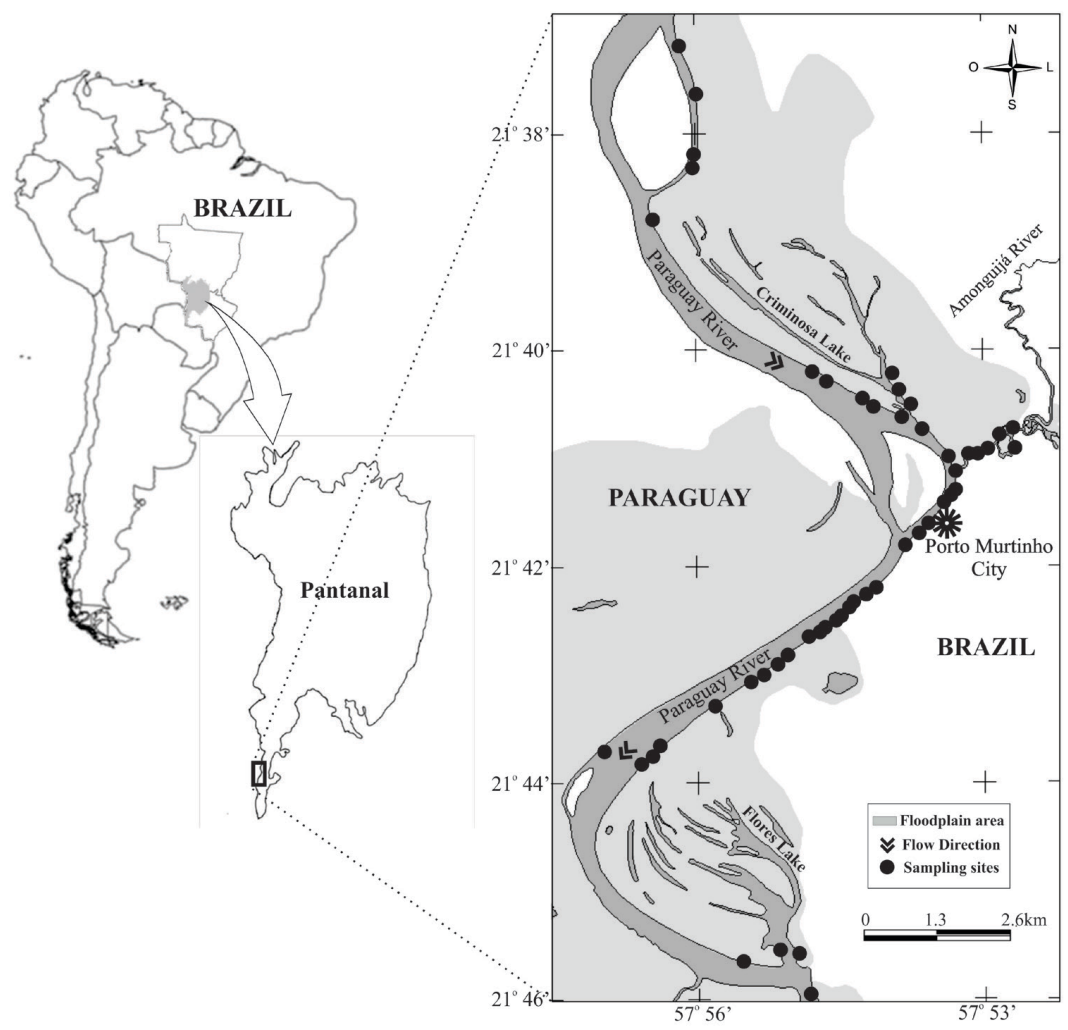

Figure 1. Location of sampling sites in the study area at Porto Murtinho, Pantanal flooplain, Brazil, from February 2009 to January 2011. 
all vitellogenic oocytes of 141 mature individuals were counted to determine fecundity.

The differences in sex ratio for the entire period and for the monthly variation were analyzed using the $\chi^{2}$ test, with Yates correction for the first case. The seasonal variation in reproduction was determined by the monthly variation in gonadosomatic index (GSI), that represents the percentage ratio between body weight $(\mathrm{W})$ and gonad weight $(\mathrm{Wg})$ using the formula $\mathrm{GSI}=100 *(\mathrm{Wg} / \mathrm{W})$ analyzed by a Kruskal-Wallis test, once data normality and homoscedasticity were not reached (Kruskal and Wallis, 1952). The seasonal variation in GSI and proportion of gonad maturity stages for females were used to define the reproductive season.

The relationships between the monthly mean values of GSI and the river water level, water temperature and rainfall were analyzed using a Spearman correlation to evaluate the influence of these environmental descriptors on reproduction of $O$. vittatus. The influence of female size on total fecundity was also estimated using a Spearman correlation test (Spearman, 1987). Size at the first sexual maturity $\left(\mathrm{L}_{50}\right)$ was estimated for males and females using a logistic regression. Being this, individuals classified as immature as defined as non reproductive (0) and individuals classified as maturing, ripe and spawned as defined as reproductive individuals (1). All statistical analyses were performed using $\mathrm{R}$ platform ( $\mathrm{R}$ Core Team R, 2017). The adopted threshold for significance was $\mathrm{p}<0.05$ for all statistical tests.

\section{Results}

A total of 1452 individuals of Otocinclus vittatus were sampled and 1066 individuals were analyzed, including 490 males, 488 females and 88 individuals of undetermined sex. The standard length varied from 10.5 to $41.25 \mathrm{~mm}$ $($ mean $=24.07 \pm 3.9)$ and total weight varied from 0.013 to $1.3 \mathrm{~g}$ (mean $=0.308 \pm 0.155)$. Considering all individuals the sex ratio has not differed from $1: 1\left(\chi^{2}=0.004 ; \mathrm{df}=1\right.$; $\mathrm{p}=0.945)$ but the ratio has varied seasonally $\left(\chi^{2}=104.90\right.$; $\mathrm{df}=23 ; \mathrm{p}<0.001)$, with the highest proportion of males in September (falling period).

We observed a significant seasonal difference in the GSI (Kruskall-Wallis $\mathrm{H}=265.2$; $\mathrm{df}=23$; $\mathrm{p}<0.001$ ), for wich highest values of GSI were observed in March, with a small reduction in April and a later increase from May to July. The GSI has changed together with the river water level (Spearman $r=0.52 ; p=0.008$ ), however it was not correlated with water temperature (Spearman $r=-0.02$; $p=0.92)$ and rainfall (Spearman $r=0.16 ; p=0.44)$. Then the main predictor of GSI was the river water level (Figure 2). Complementarily, ripe females appeared throughout the year, however a higher proportion in March and from May to July (Figure 3).

The absolute fecundity ranged from 16 to 202 vitellogenic oocytes (mean $=84.1 \pm 35.05 \mathrm{sd}$ ) and was positively correlated with standard length (Spearman $r=0.29 ; p<0.001$ ) (Figure 4). The relative mean fecundity was estimated at $0.171 \pm 0.064$ oocytes $/ \mathrm{mg}$.
The size at the first sexual maturity was estimated at $18.7 \mathrm{~mm}\left(\mathrm{CI}_{\alpha 0.05}=17.7\right.$ to $\left.19.7 \mathrm{~mm}\right)$ for females and $20.1 \mathrm{~mm}\left(\mathrm{CI}_{\alpha 0.05}=19.8\right.$ to $\left.20.5 \mathrm{~mm}\right)$ for males. All females
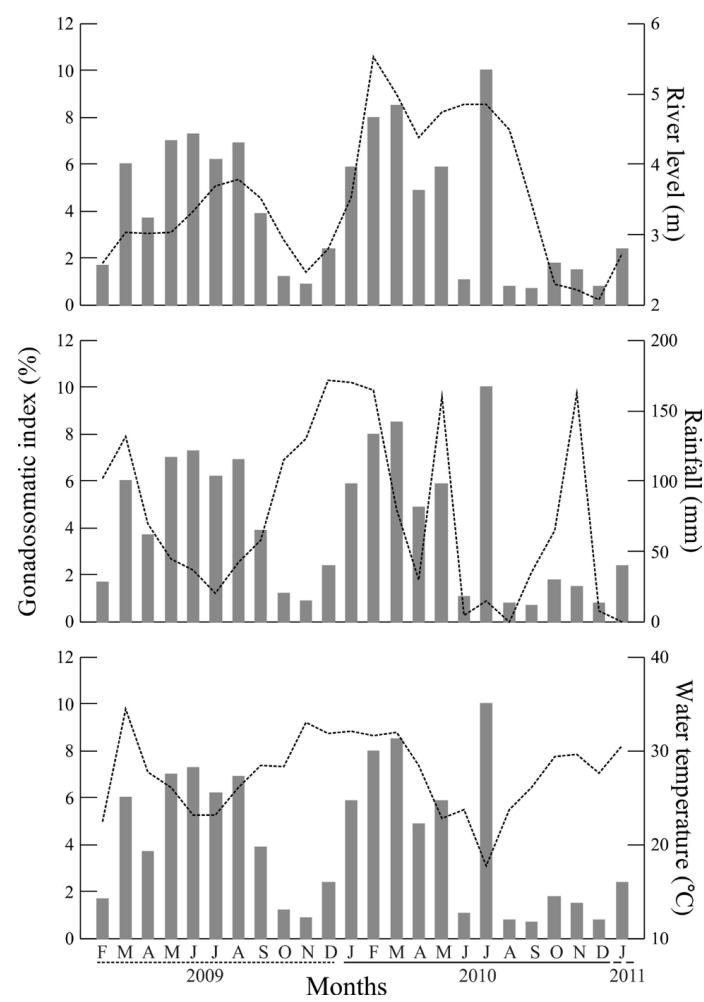

Figure 2. Seasonal variation in gonadosomatic index for Otocinclus vittatus and Paraguay River level, water temperature and rainfall (dotted line) at Porto Murtinho Pantanal, Brazil, from February 2009 to January 2011.

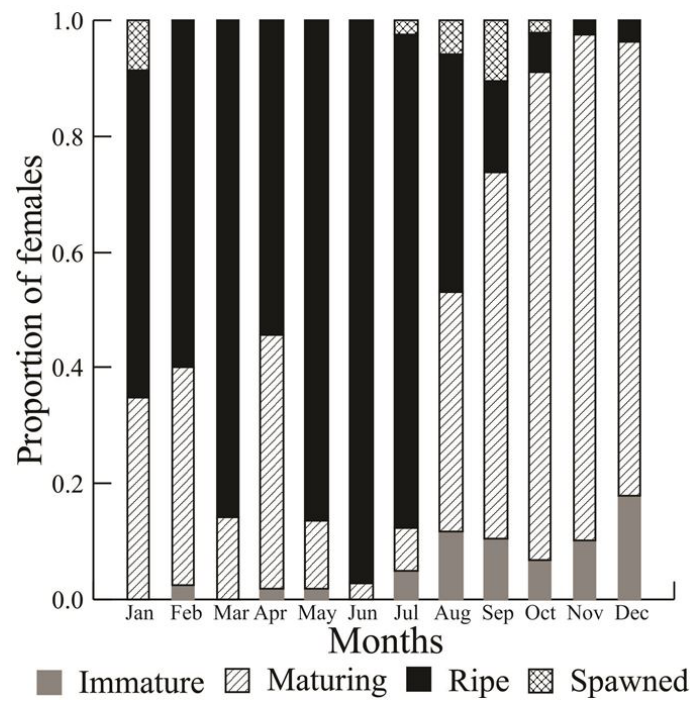

Figure 3. Seasonal variation in gonadal maturation stages for females of Otocinclus vittatus at Porto Murtinho Pantanal, Brazil, from February 2009 to January 2011. 


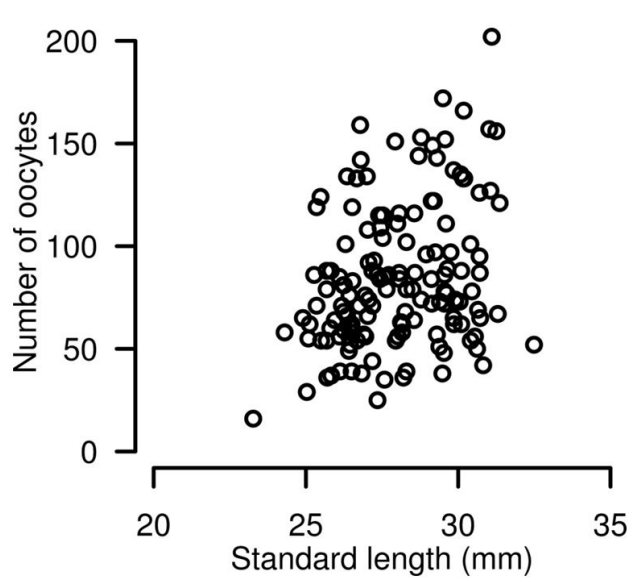

Figure 4. Scatterplot of correlation between standard length and absolute fecundity of $O$. vittatus at Porto Murtinho Pantanal, Brazil, from February 2009 to January 2011.

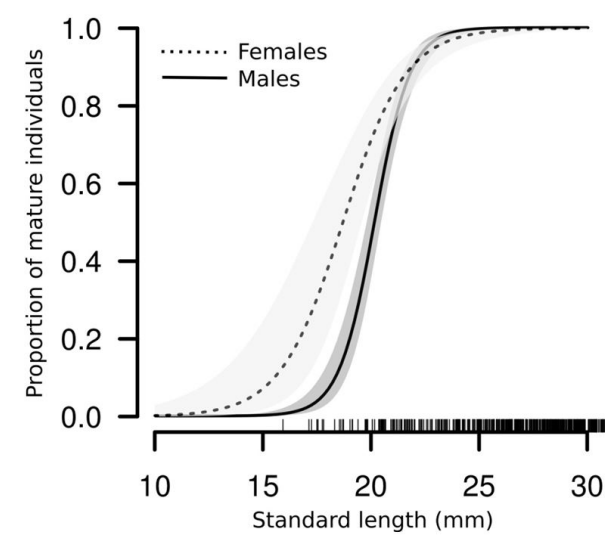

Figure 5. Size at first maturity $\left(\mathrm{L}_{50}\right)$ indicated by arrows for Otocinclus. vittatus at Porto Murtinho Pantanal, Brazil, from February 2009 to January 2011.

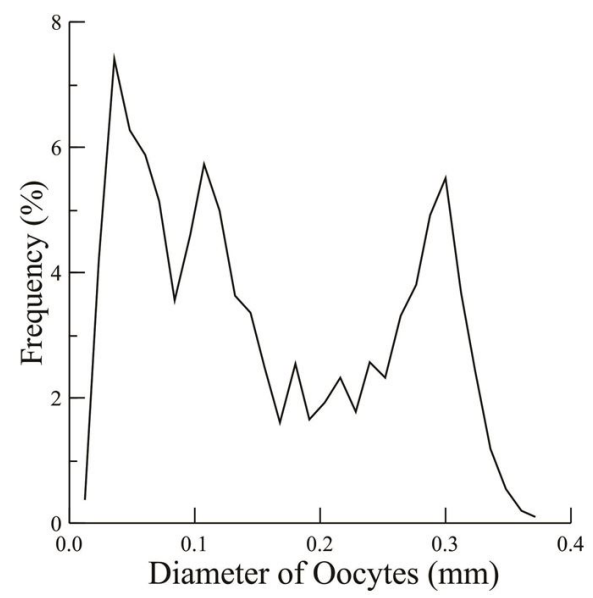

Figure 6. Distribution of oocytes diameter for Otocinclus vittatus at Porto Murtinho Pantanal, Brazil, from February 2009 to January 2011. were considered mature at $25.8 \mathrm{~mm}$, and all males were considered mature at $28.8 \mathrm{~mm}$ (Figure 5).

The diameter of oocytes varied between 0.012 and $0.37 \mathrm{~mm}$, being the vitelogenic oocytes presented mean of $0.28 \mathrm{~mm}$ $(\mathrm{SD}=0.054)$. The distribution of the frequencies of the oocyte diameters showed various modes, where the first was formed by the reserve oocytes, the intermediate by oocytes in different phases of development and the last by large, mature oocytes, indicating multiple spawning (Figure 6).

\section{Discussion}

Theoretical studies on sex ratio propose that a biased proportion acts negatively on species with one predominant sex, which will transmit their genes with proportionally lower frequency to the next generation (Fisher, 1930), and experimental studies are demonstrated the tendency to fish species converge equal sex ratio (Basolo, 1994) suggesting the robustness of this pattern. For many fish species, differences in the 1:1 pattern are considered results from differential predation, growth and/or mortality between sexes (Vazzoler, 1996). For Otocinclus vittatus, in the region sampled and considering the whole sample period, males and females are equally abundant, however, temporally, the sex-ratio changed with predominance of males only in the falling water period which may suggests differences in growth rate (Nikolsky, 1969; Garcia et al., 2004) or possibly differences in their spatial distribution in dry period as a result of reduction in macrophyte beds along the river banks (Personal observation).

The seasonality in fish reproduction depends on water temperature, rainfall and river level and has been observed in many watersheds (Vazzoler and Menezes, 1992). In our study, the reproductive period for O. vittatus in the Pantanal of Porto Murtinho occurred all over the studied year with greater reproductive intensity in months with higher water levels of the river, lower rainfall and according to the flood pulse. The positive relationship of reproduction frequency with river level observed in our study, is expected in floodplains. Zeug and Winemiller (2007) suggested that small-sized fishes with longer reproductive periods show reproductive peaks coinciding with peak river flows, as a strategy to colonize floodplain habitats, this hypothesis is corroborated by our results. Usually the reproductive period occurs in synchrony with the rainy season, river levels, and temperature; however, in this part of the Pantanal these factors are asynchronous then, higher temperature and rainfall are observed from November to February, while river level continues increasing to higher levels in June and July. This asynchronous pattern of environmental characteristics and the observed seasonal variation in $O$. vittatus reproduction also corroborate the Zeug and Winemiller (2007) hypothesis suggesting that river level are the main determinant of reproductive activity for O. vittatus in Southern Pantanal.

The flood pulse concept proposes that in rivers with flooded areas the seasonal variation in river level is the 
main driver of ecological roles in the watershed, influencing population dynamics and assemblage organization. Studies on fish reproduction have commonly encountered a seasonal pattern of reproduction, beginning in the rainy phase (Santos et al., 2010; Godinho et al., 2010) and some studies suggested that spawning is restricted to the rainy season when floods help the early life stages to reach the floodplains (Godinho et al., 2010). In studied area, $O$. vittatus occurred mainly associated to aquatic macrophytes in Paraguay and Amonguijá rivers, then is expected that the reproduction in flooding period act as strategy to the reproductive success since the increase of rainfall provides for the expansion of the habitats, which is important for its reproductive success, because allows the exploration of the new available environments as nurseries and sites of growth for the juvenils (Junk et al., 1989).

Despite this, graphically it was possible to observe a correspondence between GSI and rainfall in the first months of the studied year, suggesting that rainfall can act as a starter of breeding, which continues occurring in months with lower cumulative rainfall influenced by the higher river levels in this period. Gutreuter et al. (1999) suggested that the advantage of floodplain inundation can be greater when floods coincide with optimal temperatures, then this hypothesis corroborates our idea that the raise in water temperature can trigger the reproduction in $O$. vittatus, which can continue when river levels achieve higher values.

The small number of reproductive studies on other small loricariid species makes it difficult to compare the results obtained for $O$. vittatus with other members of this family. However the species showed a larger fecundity $($ mean $=84.1$ ) when compared with other Hypoptopomatinae species, as Hypoptopoma spectabile (H. spectabile $=$ Otocinclus spectabile) that showed a fecundity mean $=62$ (Villamil-Moreno and Arias-Castellanos, 2011). Others species of Hypoptopomatinae had fecundity low in relation to $O$. vittatus, in headwater streams of the Brazilian Atlantic Rainforest, e.g. Pareiorhina rudolphi which is larger, $($ mean $=69.5 \mathrm{TL})$ than $O$. vittatus, however present smaller mean fecundity (58 oocytes) (Braga et al., 2009). In the same habitat, Neoplecostomus microps, also larger than $O$. vittatus (total length up to $127.5 \mathrm{~mm}$ ), have the estimated mean fecundity was 49.3 oocytes (Braga et al., 2008). Comparatively, O. vittatus shows a higher mean fecundity, probably in response to higher productivity and hydrological stability of the floodplain environment in comparison to headwater streams, once, despite of great seasonal variation in river level the predictability of its occurrence leads this phenomenon to be imprinted in $O$. vittatus life history.

The difference in size at first maturity between sexes is commonly observed in fish, mainly in species with parental care. However the absence of available data for others species of Hypoptopomatinae difficult the evaluation of size at first maturation. Despite this, the unique available information suggest that females of Pareiorhina rudolphi reaches sexual maturity with $64 \%$ of maximum length (Braga et al., 2009) while for O. vittatus reach sexual maturation with approximately $45 \%$ (both sexes). Then, the higher productivity expected in Pantanal floodplain when compared with headwaters streams may be explain the smaller size at first maturation.

The spawning type is one reproductive traits adjusted by environment in that the individual lives and that determine population survival (Winemiller, 1989). For O. vittatus the analysis suggests spawning divided, because it was noted a polymodal pattern in the distribution of oocytes diameter in mature females. The multiple spawning, associated with a long reproductive period, is the main reproductive characteristics of tropical fishes (Nikolsky, 1969).

Reproductive data about Pantanal fish species are more frequent to larger and fishing target species (Resende, 1992; Resende et al., 1996; Peixer et al., 2006; Costa and Mateus, 2009; Barzotto et al., 2017; Barzotto and Mateus, 2017) and only recently smaller fish species are studied (Tondato et al., 2014; Súarez et al., 2017). Therefore the study of smaller fish species, that despite are few commercially used present great ecological importance to maintaining ecological functioning and secondary productivity of Pantanal.

Our data showed that the gonadosomatic index is strongly associated with the river level and the spawning can be triggered by an increase in rainfall, however ripe females can be found throughout the year. The analysis $O$. vittatus, suggests that spawning is divided, because a polymodal pattern is observed in the distribution of oocytes width in mature females. The mean fecundity is higher when compared to other Hypoptopomadinae in upper Paraná streams (Braga et al., 2008; Braga et al., 2009), however, the lack of information about reproductive ecology in floodplains hinders comparisons.

\section{Acknowledgements}

The authors are grateful for the financial support from the Fundação de Apoio ao Desenvolvimento do Ensino, Ciência e Tecnologia do Estado de Mato Grosso do Sul (FUNDECT) and from the Centro de Pesquisas do Pantanal (CPP/MCT). We also thank to Karina K. Tondato, Marcelo M. Souza, Wagner Vicentin, Marlon C. Pereira, Patrícia L. Rondon, Gabriela S. V. Duarte, and Fabiane S. Ferreira for help in the fieldwork. M. J. Pereira was supported by CAPES and UEMS and Y. R. Súarez is supported by productivity grants from Conselho Nacional de Desenvolvimento Científico e Tecnológico (CNPq).

\section{References}

AGOSTINHO, A.A., GOMES, L.C., VERÍSSIMO, S. and OKADA, E.K., 2004. Flood regime, dam regulation and fish in the Upper Paraná River: effects on assemblage attributes, reproduction and recruitment. Reviews in Fish Biology and Fisheries, vol. 14, no. 1, pp. 11-19. http://dx.doi.org/10.1007/s11160-004-3551-y.

BAEZA, J.A., FURLAN, M., ALMEIDA, A.C., BARROSALVES, S.P., ALVES, D.R.F. and FRASOZO, V., 2013. Population dynamics and reproductive traits of the ornamental crab Porcellana 
sayana: implications for fishery management and aquaculture. SEDAO, vol. 1, pp. 1-12.

BARZOTTO, E. and MATEUS, L.A.F., 2017. Reproductive biology of the migratory freshwater fish Salminus brasiliensis (Cuvier, 1816) in the Cuiabá River basin, Brazil. Journal of Applied Ichthyology, vol. 33, no. 3, pp. 415-422. http://dx.doi. org/10.1111/jai.13262.

BARZOTTO, E., OLIVEIRA, M. and MATEUS, L.A.F., 2017. Reproductive biology of Pseudoplatystoma corruscans (Spix and Agassiz, 1829) and Pseudoplatystoma reticulatum (Eigenmann and Eigenmann, 1889), two species of fisheries importance in the Cuiabá River Basin, Brazil. Journal of Applied Ichthyology, vol. 33, no. 1, pp. 29-36. http://dx.doi.org/10.1111/jai.13162.

BASOLO, A.L., 1994. The dynamics of Fisherian sex-ratio evolution: theoretical and experimental investigations. American Naturalist, vol. 144, no. 3, pp. 473-490. http://dx.doi.org/10.1086/285687.

BRAGA, F.M.S., GOMIERO, L.M. and SOUZA, U.P., 2008. Aspectos da reprodução e alimentação de Neoplecostomus microps (Loricariidae, Neoplecostominae) na microbacia do Ribeirão Grande, Serra da Mantiqueira oriental, Estado de São Paulo. Acta Scientiarum. Biological Sciences, vol. 30, no. 4, pp. 455-463. http://dx.doi.org/10.4025/actascibiolsci.v30i4.301.

BRAGA, F.M.S., GOMIERO, L. and SOUZA, U.P., 2009. Biologia populacional de Pareiorhina rudolphi (Loricariidae, Hypostominae) na microbacia do Ribeirão Grande, Serra da Mantiqueira oriental, Estado de São Paulo. Acta Scientiarum. Biological Sciences, vol. 31, no. 1, pp. 79-88. http://dx.doi. org/10.4025/actascibiolsci.v31i1.459.

COSTA, R.M.R. and MATEUS, L.A.F., 2009. Reproductive biology of pacu Piaractus mesopotamicus (Holmberg, 1887) (Teleostei: Characidae) in the Cuiabá River Basin, Mato Grosso, Brazil. Neotropical Ichthyology, vol. 7, no. 3, pp. 447-458. http:// dx.doi.org/10.1590/S1679-62252009000300012.

ESCHMEYER, W.N. and FONG, J.D., 2018 [viewed 4 April 2018]. Species by family/subfamily [online]. California: Institute for Biodiversity Science and Sustainability, 2018. Available from: http:/http://researcharchive.calacademy.org/research/ichthyology/ catalog/SpeciesByFamily.asp

FISHER, R.A., 1930. The genetical theory of natural selection. Oxford: Oxford University Press. http://dx.doi.org/10.5962/bhl.title.27468.

GARCÍA, G., CLARAMUNT, S. and LALANNE, A.I., 2004. Genetic differentiation among annual fishes of the genus Cynolebias (Cyprinodontiformes, Rivulidae) in a Biosphere Reserve site from Uruguay. Environmental Biology of Fishes, vol. 70, no. 3, pp. 247-256. http://dx.doi.org/10.1023/B:EBFI.0000033339.55585.f6.

GODINHO, A.L., LAMAS, I.R. and GODINHO, H.P., 2010. Reproductive ecology of Brazilian freshwater fishes. Environmental Biology of Fishes, vol. 87, no. 2, pp. 143-162. http://dx.doi. org/10.1007/s10641-009-9574-4.

GUTREUTER, S.A.D., BARTELS, K., IRONS, M. and SANDHEINRICH, B., 1999. Evaluation of the flood-pulse concept based on statistical models of growth of selected fishes of the Mississippi River system. Canadian Journal of Fisheries and Aquatic Sciences, vol. 56, no. 12, pp. 2282-2291. http:// dx.doi.org/10.1139/f99-161.

JUNK, W.J., BAYLEY, P.B. and SPARKS, R.E., 1989. The flood pulse concept in river-floodplain systems. In: Proceedings of the 106th International Large River Symposium; 1989; Canadian. Canadian: Special Publication of Fisheries and Aquatic Sciences, pp. 110-127.
KRUSKAL, W.H. and WALLIS, W.A., 1952. Use of ranks in one-criterion variance analysis. Journal of the American Statistical Association, vol. 47, no. 260, pp. 583-621. http://dx.doi.org/10.1 080/01621459.1952.10483441.

LÉVEQUE, C., OBERDORFF, T., PAUGY, D., STIASSNY, M.L.J. and TEDESCO, P.A., 2008. Global diversity of fish (Pisces) in freshwater. Hydrobiol., vol. 595, no. 1, pp. 545-567. http://dx.doi. org/10.1007/s10750-007-9034-0.

LOWE-MCCONNELL, R.H. 1999. Estudos ecológicos de comunidades de peixes tropicais. São Paulo: EDUSP, 534 p.

NIKOLSKY, G.V., 1969. Theory of fish population dynamics as the biological background for rational exploitation and management of fishery resources. 3943th ed. Edinburgh: Oliver and Boyd Ltda, 363 p.

PEIXER, J., MATEUS, L.A. and RESENDE, E.K., 2006. First gonadal maturation of Pinirampus pirinampu (Siluriformes: Pimelodidae) in the Pantanal, Mato Grosso do Sul state, Brazil. Revista Brasileira de Biologia, vol. 66, no. 1B, pp. 317-323. PMid:16710524.

R CORE TEAM R, 2017 [viewed 4 April 2018]. A language and environment for statistical computing [online]. Vienna: $\mathrm{R}$ Foundation for Statistical Computing. Available from: https:// www.R-project.org/

RESENDE, E.K., 1992. Bioecologia do curimbatá, Prochilodus lineatus no Pantanal do Miranda Aquidauana, Mato Grosso do Sul, Brasil. Acta Limnologica Brasiliensia, vol. 4, pp. 261-276.

RESENDE, E.K., CATELLA, A., NASCIMENTO, F., PALMEIRA, S.S., LIMA, M.S. and PEREIRA, R., 1996. Biologia do curimbatá (Prochilodus lineatus), pintado (Pseudoplatystoma corruscans) e cachara (Pseudoplatystoma fasciatum) na bacia hidrográfica do rio Miranda, Pantanal do Mato Grosso do Sul, Brasil. Boletim de Pesquisa, vol. 1, pp. 1-75.

RHYNE, A., ROTJAN, R., BRUCKNER, A. and TLUSTY, M., 2009. Crawling to collapse:ecologically unsound ornamental invertebrate fisheries. PLoS One, vol. 4, no. 12, pp. e8413. http:// dx.doi.org/10.1371/journal.pone.0008413. PMid:20027312.

SANTANA, C.A., TONDATO, K.K. and SÚAREZ, Y.R., 2018. Reproductive biology of Hyphessobrycon eques (Characiformes: Characidae) in Southern Pantanal, Brazil. Brazilian Journal of Biology. http://dx.doi.org/10.1590/1519-6984.176273.

SANTOS, R.N., AMÁDIO, A.S. and FERREIRA, E.J.G., 2010. Patterns of energy allocation to reproduction in three Amazonian fish species. Neotropical Ichthyology, vol. 8, no. 1, pp. 155-161. http://dx.doi.org/10.1590/S1679-62252010005000001.

SPEARMAN, C., 1987. The proof and measurement of association between two things. By C. Spearman, 1904. The American journal of psychology, vol. 100, no. 3-4, pp. 441-471. http://dx.doi. org/10.2307/1412159. PMid:3322052.

SÚAREZ, Y.R., SILVA, E.A. and VIANA, L.F., 2017. Reproductive biology of Astyanax lacustris (Characiformes: Characidae) in the southern Pantanal floodplain, upper Paraguay River basin, Brazil. Environmental Biology of Fishes, vol. 100, no. 7, pp. 775-783. http://dx.doi.org/10.1007/s10641-017-0604-3.

TONDATO, K.K., FIALHO, C.B. and SÚAREZ, Y.R., 2013. Reproductive ecology of Odontostilbe pequira (Steindachner, 1882) (Characidae, Cheirodontinae) in Paraguay River, southern Pantanal, Brazil. Environmental Biology of Fishes, vol. 97, no. 1, pp. 13-25. http://dx.doi.org/10.1007/s10641-013-0119-5. 
TONDATO, K.K., FIALHO, C.B. and SÚAREZ, Y.R., 2014. Reproductive ecology of Odontostilbe pequira (Steindachner, 1882) (Characidae, Cheirodontinae) in the Paraguay River, southern Pantanal, Brazil. Environmental Biology of Fishes, vol. 97, no. 1, pp. 13-25. http://dx.doi.org/10.1007/s10641-013-0119-5.

VAZZOLER, A.E.A.M. and MENEZES, N.A., 1992. Síntese de conhecimentos sobre o comportamento reprodutivo dos Characiformes da América do Sul (Teleostei, Ostariophysi). Revista Brasileira de Biologia, vol. 52, pp. 627-640.

VAZZOLER, A.E.A.M., 1996. Biologia da reprodução de peixes teleósteos: teoria e prática. Maringá: EDUEM, 169 p.

VILLAMIL-MORENO, L.P. and ARIAS-CASTELLANOS, J.A., 2011. Fecundidad de Otocinclus spectabilis. Orinoquia
(Universidad Tecnologica de los Llanos Orientales), vol. 15, no. 1, pp. 41-47. http://dx.doi.org/10.22579/20112629.41.

WINEMILLER, K.O., 1989. Patterns of variation in life history among South American fishes in seasonal environments. Oecologia, vol. 81, no. 2, pp. 225-241. http://dx.doi.org/10.1007/ BF00379810. PMid:28312542.

WOOTTON, R.J., 1991. Ecology of freshwater fishes. London: Chapman and Hall. 212 p.

ZEUG, S.C. and WINEMILLER, K.O., 2007. Ecological correlates of fish reproductive activity in floodplain rivers: a life-history-based approach. Canadian Journal of Fisheries and Aquatic Sciences, vol. 64, no. 10, pp. 1291-1301. http://dx.doi. org/10.1139/f07-094. 